\title{
PELATIHAN PENGELOLAAN PERSEDIAAN, PENGEMASAN，DAN PEMANFAATAN APLIKASI GO-FOOD (GOJEK) UNTUK UMKM KAMPUNG TEMPE SURABAYA
}

\author{
Hendri Soekotjo"), Krido Eko Cahyono²), Pontjo Bambang ${ }^{3)}$, Novianto Eko Nugroho4), Okto Aditya \\ Suryawirawan ${ }^{5}$ \\ 1,2,3,4,5Sekolah Tinggi Ilmu Ekonomi Indonesia (STIESIA) Surabaya

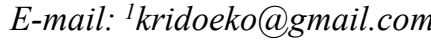

\begin{abstract}
Abstrak
Kampung tempe merupakan kumpulan masyarakat pelaku UMKM pembuat tempe tradisional secara turun temurun. Kondisi ini menyebabkan jumlah pembuat tempe semakin langka dan ratarata usia senja yang berlokasi di sentra kampung tempe tenggilis kauman surabaya. Pelaku UMKM pembuat tempe di kampung tempe tenggilis kauman ini dalam menjalankan usahanya memiliki beberapa kendala untuk mengembangkan usahanya seperti a) pemasaran dan pangsa pasar produk tempe masih terbatas, serta belum mengenai toko online, b) desain label dan banner masih tradisional, c) pengelolaan persediaan masih tradisional d) belum bekerjasama dengan dengan restoran. Tujuan pelaksanaan pengabdian masyarakat dalam bentuk pelatihan ialah memfasilitasi para pelaku UMKM kampung tempe agar memiliki keterampilan dalam penggunaan aplikasi online untuk memasarkan produknya, sehingga dilakukan perlu adanya pelatihan sebagai berikut a) pemasaran dan perluasan pangsa pasar dengan memanfaatkan toko online, b) re-design label dan banner agar lebih menarik dan unik, serta c) pengelolaan persediaan dengan aplikasi android, d) pengenalan aplikasi gojek (go-food) dengan memanfaatkan merchant. Diharapkan dengan pengabdian masyarakat dalam bentuk pelatihan ini berguna untuk usahanya dalam mengembangkan produk UMKM.
\end{abstract}

Kata Kunci : Pengelolaan Persediaan, Pengemasan, Aplikasi Gojek, Kampung Tempe

\begin{abstract}
Tempe village is a collection of community members of MSMEs that make traditional tempe for generations. This condition causes the number of tempe makers to become increasingly scarce and the average age of the twilight located in the village of tempe tenggilis surabaya. The SMEs who make tempe in the village of tempe tenggilis kauman in running their business have several obstacles to develop their business such as a) marketing and market share of tempe products are still limited, and not yet about online shops, b) label and banner designs are still traditional, c) inventory management still traditional d) has not collaborated with restaurants. The purpose of implementing community service in the form of training is to facilitate the SMEs of tempe village entrepreneurs to have the skills in using online applications to market their products, so that training is needed as follows: a) marketing and expanding market share by utilizing online stores, b) re-design labels and banners to make it more attractive and unique, and c) inventory management with an android application, d) introduction of go-food applications by utilizing erchants. It is expected that community service in the form of training will be usefull for its efforts in developing SME products.
\end{abstract}

Keywords : Inventory Management, Packaging, Gojek Application, Tempe village 


\section{PENDAHULUAN}

Produk makanan tempe merupakan makanan tradisional yang diminati oleh masyarakat Indonesia, karena harga yang murah, kandungan protein nabati yang tinggi. Hal ini menunjukkan bahwa eksistensi produk makanan tradisional tempe masih banyak dijual di pasar tetapi juga dapat kita temui di outlet restoran dalam negeri bahkan restoran di luar negeri dalam bentuk kripik tempe bermacam rasa.

Tempe merupakan makanan tradisional masyarakat Indonesia yang didalam terdapat kacang kedelai sebagai bahan utama yang dilakukan fermentasi menggunakan bahan kapang rhizopus / ragi tempe.

Salah satu lokasi UMKM pembuat tempe yang terdapat di Surabaya yaitu di Tenggilis Kauman Surabaya, dikenal sebagai kampung tempe lantaran profesi penduduk sebagai wirausaha yang memproduksi tempe. Sejarahnya terbentuknya identitas sebagai kampung tempe diketahui sekitar tahun 1970, terdapat pelaku UMKM produsen tempe yang ada sekitar 200 orang, namun seiring berjalannya waktu saat ini hanya menyisakan sekitar 5 kepala keluarga orang yang masih berkecimpung dalam usaha pembuatan tempe. Eksistensi para pelaku UMKM kampung tempe tenggilis kauman surabaya dapat dimanfaatkan menjadi referensi bagi warga Surabaya yang hendak mempelajari proses bisnis dan produksi tempe.

Kampung tempe yakni kumpulan masyarakat para pelaku UMKM pembuat tempe. Sesuai Undang Undang Nomor 20 tahun 2008, Usaha Mikro Kecil dan Menengah adalah salah satu sektor rill primer yang memberikan sokongan sebagai percepatan tingkat pertumbuhan ekonomi di kota Surabaya, lantaran tenaga kerja yang menjadi pelaku UMKM sangat besar dan sangat erat dengan masyarakat kalangan lemah. Sebagai institusi pemerintah dalam hal ini pemkot Surabaya melalui Dinas Koperasi Dan UMKM sangat membantu eksistensi para pelaku UMKM yang ada di Surabaya dengan mengadakan pelatihan dalam memproduksi olahan dari kedelai seperti Keripik Tempe, Saridele, dan lain-lain yang sudah dipasarkan melalui restoran dan outlet oleh-oleh yang dikelola Pemerintah Kota Surabaya.

Selain pelaku UMKM agar dapat memasarkan produk membutuhkan design banner dan label untuk produk olahan tempe dengan pengemasan produk yang menarik dan unik."Kotler \& Keller (2009), pengemasan adalah kegiatan mendesain dan memproduksi kemasan atau bungkus sebagai sebuah produk."

"Pengemasan suatu produk dilakukan oleh produsen untuk bisa mendapat minat konsumen terhadap pembelian barang, produsen berupaya memberi kesan yang baik pada kemasan produk dan membuat model kemasan baru yang berbeda dengan produk sejenis pada pasar yang sama sebagaimana fungsi utama dari kemasan adalah untuk menjaga produk, akan tetapi sekarang kemasan menjadi unsur yang penting sebagai media pemasaran (Rangkuti, 2010)."

"Potensi usaha yang beraneka ragam yang ada di kota Surabaya menjadi sumber mata pencaharian utama penduduk mulai dari industri makanan, kerajinan, tekstil, dan agrobisnis yang menunjukkan trend positif terlihat dari perkembangan jumlah pelaku UMKM di Surabaya periode tahun 20142017 yaitu :

\section{Tabel 1}

Perkembangan Jumlah UMKM Surabaya

\begin{tabular}{|c|c|c|}
\multicolumn{2}{c|}{ Tahun 2014-2017 } \\
\hline \multirow{2}{*}{ Tahun } & $\begin{array}{c}\text { Jumlah } \\
\text { UMKM }\end{array}$ & $\begin{array}{c}\text { UMKM } \\
\text { (orang) }\end{array}$ \\
\hline 2014 & 25.353 & 27.926 \\
2015 & 25.147 & 28.391 \\
2016 & 26.037 & 28.759 \\
2017 & 26.800 & 29.507 \\
\hline
\end{tabular}

Sumber: Dinas Koperasi \& UMKM, 2017

Melihat data perkembangan jumlah pelaku UMKM di Surabaya periode tahun 2014-2017 menunjukkan tren bertumbuh dari 25.353 (tahun 2014) menjadi 26.800 (tahun 2017). Akan tetapi tren positif jumlah UMKM tidak lepas dari permasalahan yang sering dihadapi oleh UKM adalah salah satunya adalah pemasaran produk UMKM. 
Pemasaran produk yang digunakan pelaku UMKM masih terkendala biaya yang tinggi. Pelaku UMKM perlu merevolusi proses transaksi jual beli yang mengakomodir permasalahan konsumen melalui media toko online.

Melihat hal tersebut, maka kegunaan menciptakan toko online akan membuat nilai tambah bagi seseorang yang ingin memulai usaha baru tapi tidak memiliki toko secara fisik.

"Untuk meningkatkan pangsa pasar mereka, terdapat beberapa alat pemasaran yaitu konsep bauran pemasaran (Marketing Mix) terdiri dari $4 \mathrm{p}$, yaitu : product, price, place, dan promotion. Bauran pemasaran tersebut saling berkaitan dan memiliki daya saing yang optimal sesuai dengan karakteristik segmennya (Kotler dan Keller, 2016).

STIESIA Surabaya melalui kegiatan pengabdian masyarakat memberikan Pelatihan Pengelolaan Persediaan, Pengemasan, Dan Pemanfaatan Aplikasi GoFood (Gojek) untuk kelompok pelaku UMKM (Usaha Mikro Kecil Menengah). Agar para pelaku UMKM ini dapat memiliki keterampilan dalam penggunaan aplikasi online untuk memasarkan produknya.

Materi pelatihan yang diberikan adalah tentang prosedur pendaftaran merchant di aplikasi online Gojek (Go-Food). Kemampuan yang telah dimiliki oleh pelaku UMKM setelah pelatihan akan sangat bermanfaat. Selain itu kegiatan pengabdian ini dapat menjadi salah satu promosi untuk memulai usaha baru di era teknologi dalam mengembangkan produk usahanya.

Era sekarang ini agar sukses berwirausaha, maka wirausahawan tidak lagi harus memiliki toko secara langsung, dengan menggunakan teknologi toko online, banyak orang yang sukses menjalankan usahanya. Bahkan ruang usahanya dapat melebihi usaha yang dilakukan dengan toko tradisional. Dengan membuat toko online, kendala tempat tidak akan menjadi masalah lagi. Bahkan pembeli dari luar negeri dapat membeli melalui online produk yang dijual.
Benefit ini tidak dimiliki semua usaha yang dilakukan secara tradisional.

Benefit memiliki toko online semakin memudahkan pelaku UMKM seperti produsen tempe yang harus memiliki persediaan bahan baku untuk melakukan produksi setiap harinya. Mulyadi (2014) mengatakan bahwa terdapat dua jenis metode pencatatan persediaan, yaitu Metode Persediaan Fisik (physical inventory method) dan Metode Mutasi Persediaan (perpetual inventory method). Untuk melihat jumlah stock persediaan barang dagang pada perusahaan harus menggunakan pencatatan dalam kartu stock, maka produsen tempe harus mempunyai pencatatan persediaan untuk memperkirakan barang harus ditambahkan atau dikurangi dengan menggunakan aplikasi inventory stock.

Dengan teknologi internet sekarang ini, setiap orang dapat melakukan pembelian barang secara online. Sehingga bagi konsumen yang sibuk, dan jaraknya cukup jauh maka pembelian bisa dilakukan secara online dan ini merupakan salah satu solusi. Sehingga kedepan akan sangat banyak orang yang berbelanja menggunakan teknologi secara online.

\section{METODE PELAKSANAAN}

Tahapan dan rencana pelaksanaan kegiatan pengabdian masyarakat di Kampung Tempe Tenggilis Kauman Surabaya, sebagai berikut :

1) Melakukan identifikasi data pada calon obyek pengabdian masyarakat,

2) Melakukan survei lapangan dan koordinasi antara tim pengabdian masyarakat STIESIA Surabaya dengan ketua kelompok terkait rencana melaksanakan pengabdian masyarakat di Kampung Tempe Tenggilis Kauman.

3) Melakukan persiapan dan penetapan jadwal pelaksanaan kegiatan pengabdian masyarakat di Kampung Tempe Tenggilis Kauman.

4) Melakukan koordinasi antara tim pengabdian masyarakat STIESIA Surabaya dengan mitra PT. Gojek Indonesia terkait rencana 
melaksanakan pengabdian masyarakat di Kampung Tempe Tenggilis Kauman.

5) Membuat strategi melakukan pemasaran.

6) Membantu dalam pengelolaan persediaan bahan baku produksi tempe dengan aplikasi android stock opname

7) Membantu dalam mendesain banner dan label nama serta sistem pengemasan yang menarik dan unik pada kemasan produk olahan tempe agar lebih menarik minat pembeli.

8) Membuat materi promosi keberadaan kampung tempe melalui aplikasi Gojek agar semakin banyak masyarakat yang mengetahui keberadaan kampung tempe.

\section{HASIL DAN PEMBAHASAN}

Kegiatan pelaksanaan pengabdian masyarakat dilakukan pada tanggal 5 November 2019, pukul 19.00 WIB bertempat di Rumah Pak Nurhasan, Kampung Tempe yang terletak di Jalan Tenggilis Kauman gang Buntu RT 04 RW III Surabaya, yang diikuti oleh 15 pelaku UMKM tempe, 5 orang narasumber dan 1 orang mahasiswa yang ikut terlibat pada kegiatan Pengabdian Masyarakat di Kampung Tempe Tenggilis Kauman.

Berdasarkan hasil pelatihan dan diskusi permasalahan yang menjadi fokus pelaksanaan pada kegiatan pengabdian masyarakat ini, yaitu :

1) Permasalahan dalam strategi pemasaran produk

2) Permasalahan pengelolaan persediaan barang yang belum efektif dan efisien

3) Permasalahan kemasan produk dan label produk yang kurang menarik dan unik.

4) Permasalahan promosi produk olahan tempe belum dikenal masyarakat luas.

Rincian pelaksanaan kegiatan yang telah dilakukan oleh Tim Pengabdian Masyarakat bersama mitra Gojek sebagai berikut :

1) Sambutan dari Pak Supardam selaku RT.04 RW.03 dan perwakilan tim

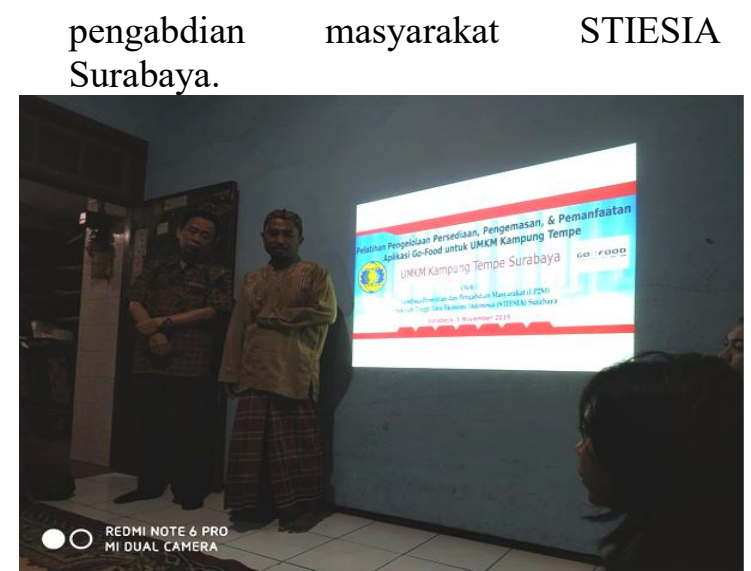

2) Penjelasan materi pengelolaan persediaan dan pengemasan produk
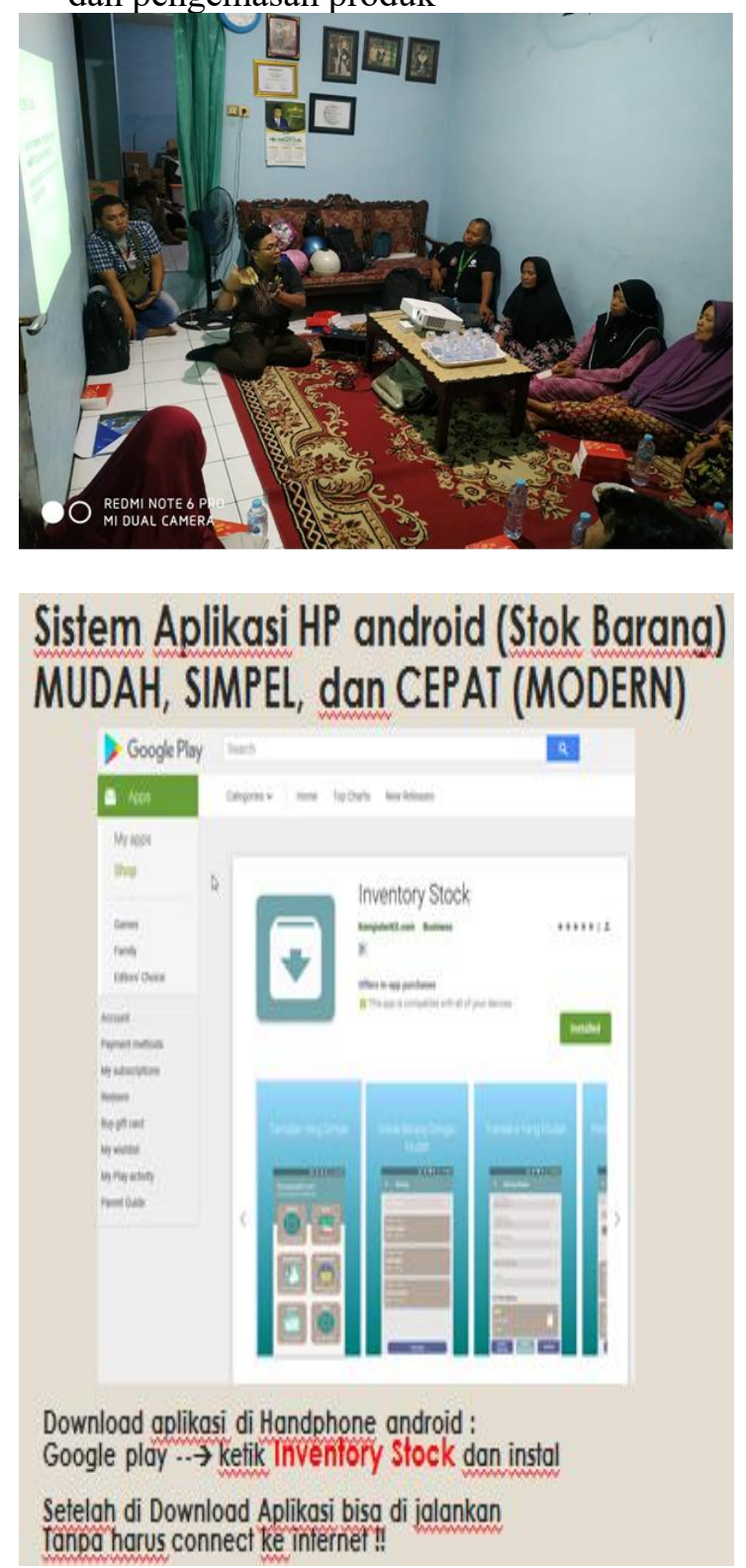


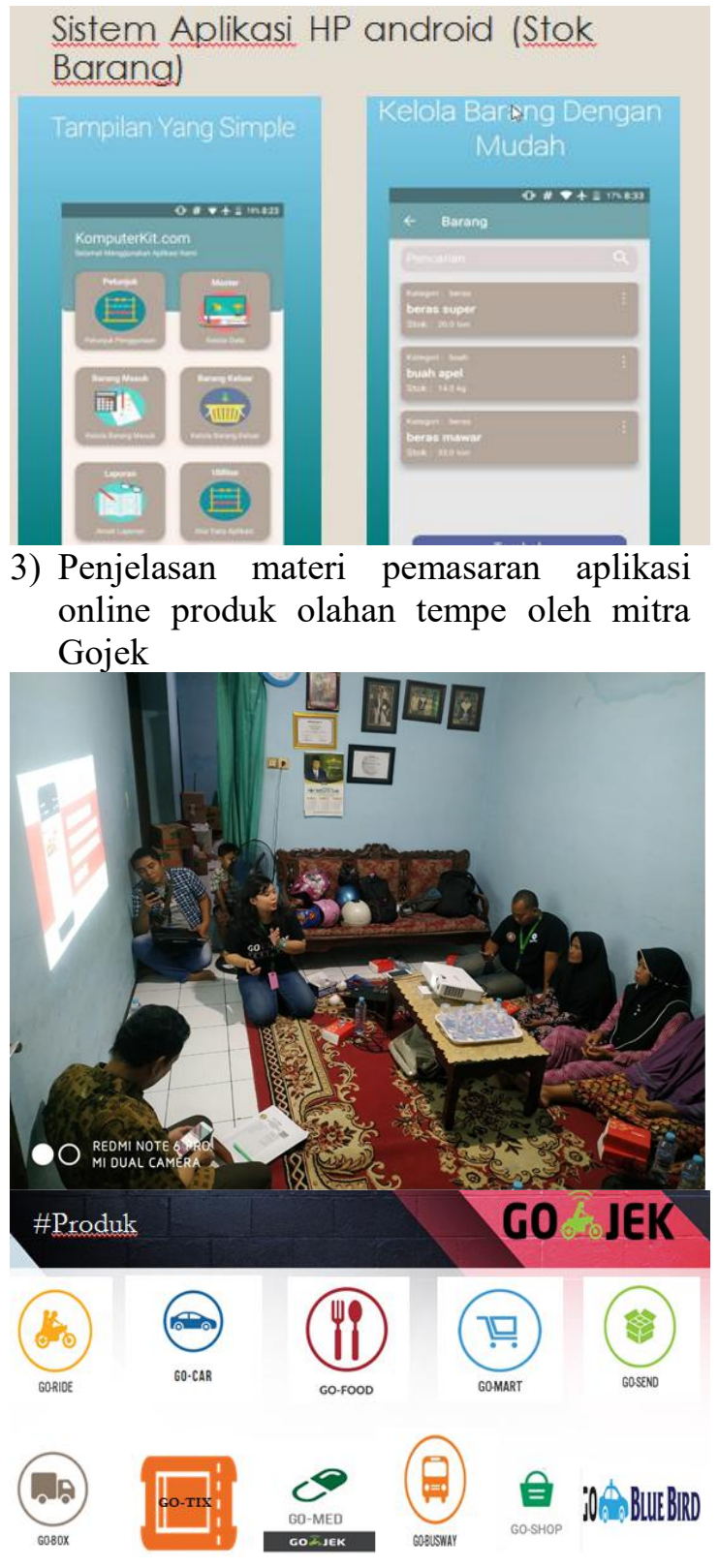

4) Foto Bersama setelah penjelasan materi dan diskusi.

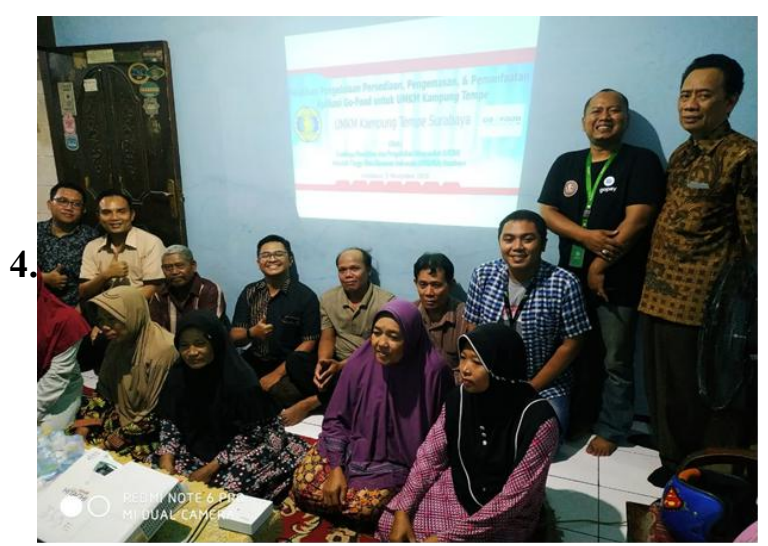

dengan menggunakan aplikasi Gojek (GoFood).

Selain itu diharapkan agar para pelaku UMKM memiliki keinginan untuk berwirausaha dengan menjual produknya melalui online atau menjual jasa pembuatan toko online.

\section{UCAPAN TERIMA KASIH}

Melalui artikel ini penulis mengucapkan terima kasih yang sebesarbesarnya kepada beberapa pihak:

1) Ketua Sekolah Tinggi Ilmu Ekonomi Indonesia (STIESIA) Surabaya yang telah memberikan fasilitas dalam pelaksanaan kegiatan Pengabdian Kepada Masyarakat sebagai salah satu pemenuhan Tridharma Perguruan Tinggi.

2) Kepala Lembaga Penelitian dan Pengabdian Kepada Masyarakat (LP2M) yang telah memberikan fasilitas dan mengkoordinatori kegiatan pengabdian dengan beberapa UMKM di Surabaya.

3) Ketua RT. 04 Pak Supardam dan Ketua Kelompok Kampung Tempe Tenggilis Kauman yang telah menyediakan tempat kegiatan Pelatihan Pengelolaan Persediaan, Pengemasan, Dan Pemanfaatan Aplikasi Go-Food (Gojek) untuk kelompok pelaku UMKM (Usaha Mikro Kecil Menengah).

4) Seluruh peserta pelatihan dari pelaku UMKM Kelompok Kampung Tempe Tenggilis Kauman.

\section{REFERENSI}

Kotler, Philip and Kevin Lane Keller, 2016. Marketing Management, 15th Edition, Pearson Education, Inc.

Kotler dan Keller. 2009. Manajemen Pemasaran. Jilid I. Edisi ke 13. Jakarta: Erlangga.

Mulyadi. 2014. Sistem Akuntansi. Cetakan Keempat. Jakarta : Salemba Empat. 
VOL. 04. NO. 1, 1 Juli 2020

Undang-undang Nomor 20 Tahun 2008 Tentang Usaha Mikro, Kecil dan Menengah. 